\title{
FORMS OF CONFLICT REGULATION IN PRE-REVOLUTIONARY DAGESTAN
}

\author{
(C) Sarat G. Hiyasova, Maida G. Mustafaeva, Elmira Sh. Musaeva
}

\author{
Dagestan State Pedagogical University, Makhachkala, \\ Republic of Dagestan, Russian Federation \\ science-almanac@mail.ru
}

Forms of conflict regulation in pre-revolutionary Dagestan are analyzed: Maslaat (an arbitrational or mediatory method of conflict regulation, which has become common in the North Caucasus) and Adat (a custom, relic norms of pre-Islamic legal complexes, a set of rules of a customary law among Dagestan peoples). Various models of their implementation in the traditional pre-revolutionary culture of the peoples of Dagestan are revealed. Features of Dagestan Adats of different societies and settlements are noted. These features are manifested in the fact that, for all the unity and external similarity of codes and provisions, no paragraph repeats the other literally, that is, all of them are of a private nature. The authors analyze the origins of Adats in Dagestan and note that each community (jamaat) had its own code on the basis of common, i.e. single Adat right in Dagestan is divided into many codified codes. Each code fell into Adats of specific communities. The reasons of sustainability of these forms in society are investigated, despite numerous attempts to introduce Shariat norms in pre-revolutionary Dagestan, and the main factors by which Shariat has not displaced Adats are being identified. According to the authors among such factors there is, for example, the fact that Adats got into the life of the Highlanders firmly, and became the basis of their lifestyle and morality. They were more understandable for the Highlanders, as they provided for less stringent punishments than Shariat. Adats were means of replenishment of the budget of leadership elite: bek (the category of privileged population), uzden (the feudal class in the Caucasus), etc. In their elimination the last saw a real threat of their financial wellbeing. The significance and relevance of Adats and Maslaat in modern society are justified and their role in modern culture of Dagestan peoples is determined.

Key words: Maslaat, Adat, culture, Dagestan, peoples, right, crimes, punishments, conflicts.

\section{[С.Г. Хиясова, М.Г. Мустафаева, Э.Ш. Мусаева Формы регулирования конфликтов в дорево- люционном Дагестане]}

Анализируются формы регулирования конфликтов в дореволюционном Дагестане: маслаат (третейский или посреднический способ урегулирования конфрликтов, получивший распространение на Северном Кавказе) и адат (обычай, пережиточные нормы доисламских правовых комплексов, совокупность норм обычного права у дагестанских народов). Раскрываются различные модели их реализации в традиционной дореволюционной культуре народов Дагестана. Отмечаются особенности дагестанских адатов разных обществ и поселений. Эти особенности проявляются в том, что при всем единстве и внешней схожести кодексов и положений ни один пункт не повторяет другой буквально, т.е. все они носят партикулярный (частный) характер. Авторы анализируют истоки происхождения адатов в Дагестане и отмечают, что каждая община (джамаат) имела собственный кодекс на основе общего, т.е. единое адатное право в Дагестане разделено на множество кодифицированных сводов. Каждый свод распадался на адаты конкретных общин. Выясняются причины устойчивости этих форм в обществе, несмотря на многочисленные попытки внедрения в дореволюционном Дагестане норм шариата, и указываются основные факторы, по которым шариат не вытеснил адаты. К таким факторам авторы относят, например, то, что адаты прочно вошли в быт горцев, стали основой образа жизни и нравственности. Они были более понятны горцам, так как предусматривали менее строгие, чем шариат наказания. Адаты являлись средством пополнения бюджета правящей верхушки (беков, узденей и т.д.). В их ликвидации последние видели реальную угрозу своего финансового благополучия. Обосновывается значимость и актуальность адатов и маслиата в современном обществе и определяется их роль в современной культуре дагестанских народов.

Ключевые слова: маслаат, адат, культура, Дагестан, народы, право, преступления, наказания, конфрликты. 
Sarat G. Hiyasova - Ph.D. in Pedagogy, Associate Professor, Dagestan State Pedagogical University, Makhachkala, Republic of Dagestan, Russian Federation.

Maida G. Mustafaeva - Ph.D. (Advanced Doctorate) in Philosophy, Professor, Dagestan State Pedagogical University, Makhachkala, Republic of Dagestan, Russian Federation.

Elmira Sh. Musaeva - Ph.D. in Philosophy, Associate Professor, Dagestan State Pedagogical University, Makhachkala, Republic of Dagestan, Russian Federation.

Хиясова Сарат Гасановна - кандидат педагогических наук, доцент, Дагестанский государственный педагогический университет, г. Махачкала, Республика Дагестан, Российская Федерация.

Мустафаева Маида Ганифраевна - доктор философских наук, профессор, Дагестанский государственный педагогический университет, г. Махачкала, Республика Дагестан, Российская Федерация.

Мусаева Эльмира Шекералиевна - кандидат фрилософрских наук, доцент, Дагестанский государственный педагогический университет, г. Махачкала, Республика Дагестан, Российская Федерация.

Maslaat. The system of community administration and rural justice of the people of Dagestan during the period under review was based on Adat law, Shariat law, as well as on the forms of truce (Maslaat).

It is generally accepted that the main authority of formation and development of formation of Adat of the Caucasus peoples was arbitration, i.e. the magistrate's court with the help of intermediaries. Various proceedings, conflicts, which were resolved with the help of intermediaries chosen by litigants, became the main source of formation of new mountain Adats. Authoritative people, wise old people, well-versed in folk customs, having an experience of such proceedings in the past were usually invited to resolve controversial issues.

Despite a large number of fatal incidents, in Dagestan the murder of a person was considered a great tragedy not only for the family of the victim, but also for the relatives of the killer. The situation was exacerbated by the fact that, owing to the established custom of blood revenge at that time, innocent people, namely close relatives of the killer, could have suffered because of their blood affiliation with the killer. Therefore, in Dagestan people resorted to the traditional forms of conflict regulation established in society at that time as much as possible.

Historically, in the case of ancestral disputes, the elders in the genus consulted, collected Maslaat to settle the case, negotiated, and no one contradicted them. Over time, the population grew, there were more and more litigations. The court of the elders in the genus became no longer sufficient, because it was difficult to monitor the implementation of its orders. Nevertheless, the mediation court remained an authoritative institution in resolving conflicts of various kinds. People resorted to Maslaat or to reconciliation everywhere in Dagestan. The arguing people were reconciled with the help of requests, rewards, concessions. The feature of Maslaat is that it was committed by independent judges elected from honorary third parties. This often excluded the bias of their decisions.

Maslaat procedure carried out in case of consent to the truce of the injured party was very interesting. Let's give as an example one of its common forms in traditional culture. After waiting for the time set by Adat (custom), the relatives of the perpetrator (killer) gathered in a pre-marked and negotiated place and headed to the house of the victim. This march was completed by the killer himself, a potential blood enemy, the one whose fault could have led to the blood feud. The column was headed by respected people of the village (elders), relatives of the perpetrator, sometimes representatives of the clergy. The clergy in this situation tended to emphasize the obligation of the truce, stressing that the best representatives of Islam always solicited a truce and cited precedents from the past. 
It should be noted that the rite of truce, Maslaat, among different peoples of Dagestan was embodied in various and very original forms. Thus, for example, among such mountain people of Dagestan as Khwarshi people, relatives of the perpetrator literally crawled on knees to the place of reconciliation, closing the procession. They monotonously with crying quoted prayers, beat themselves in the chest. The killer in front of the column also crawled on his knees, usually with his head uncoated. This example is very indicative because it demonstrates that moral compensation in the form of insults and humiliation of the killer and his family was often more important than material compensation. If the side of the victim was ready to forgive the perpetrator, after observing this rite, the relative of the victim took a knife and cut a strand of hair from the head of the blood enemy, lifting it from the knees, this meant forgiveness. It is indicative that the raced killer at times became a blood brother, that could be interpreted to some extent as replacing the victim in the family.

Adats are described in detail by Manai Alibekov in his "Adats of Kumyks". Adats during the murders reveal the procedure of reconciliation of the warring parties in detail interestingly. This kind of researches show that the process of truce (Maslaat) in the traditional culture of pre-revolutionary Dagestan was detailed. Let us give it as an example for revealing the essence of the truce rite, as in one form or another this rite was also observed among other peoples of Dagestan.

Shortly after the murder the man who committed the murder took refuge with his paternal relatives in his Prince's house. The Prince, according to the customs and traditions of Dagestan, had to take them under his protection and patronage. He took the lead in the cases of the killer he had sheltered in order to prevent retaliatory bloodshed, for reassure the victims, before the killer reconciled with the injured party. He sometimes gathered his uzdens and milk relatives (relatives which were breast-fed) as a help. The Prince fed the whole sheltered genus of the killer until the end of all the troubles of reconciliation between the parties. For the purposes of moral support and following the custom, fellow villagers and friends came to the Prince's house as well as to the victims. They expressed their condolences to them, they usually said: "God will send his peace". Relatives of the killer in the Prince's house performed a rite of mourning of the victim (held "Yassa") and at the same time cursed and abused out their relative, the killer. The Prince, having waited for the end of the ritual of mourning at the victim 's house, sent his qadi (the judge) and two "tamazes" (honorary old men) to negotiate reconciliation with the relatives of the killer. In case the relatives of the victim did not agree to forgive the killer, the envoys of the Prince offered to evict the killer far from the native aul (according to the Adat of the kanly (blood enemy)) and at the same time asked to reconcile with the relatives of the killer. If, for the first time, negotiations were unsuccessful and the envoys were sent back to the Prince without result, the Prince sent them for the second and third time until the relatives of the victim agreed to reconcile. It should be stressed that in the latter case the so-called "alym" (payment) presented to the family of the victim was collected from the family of the killer. "Alym from smoke", that is, from the relatives, tasting "from one boiler" (figuratively speaking) has long been installed in one sheep. Later alym was set in money. In case when the relative of the killer did not wish to take part in alym, the relatives of the victim had the right to kill. Of course, alym was big in the family where there were a lot of relatives and it was small where there were few. If the killer had a small genus and it was consisted of poor relatives, these relatives did not participate in alym.

So, when alym was collected the messenger was sent to the relatives of the victim to say that "we are going with alym". The relatives of the killer with the honorary old men of the aul, the cadi, and the Prince in the lead giving alym to the cadi, were on their way to the house where the deceased was mourned. In advance, the killer's relatives took off all weapons and shoes. Being barefoot, lifting the pants above the knees, removing papakhas 
(tall Caucasian fur hats) the killer's relatives were walking to their destination. When this procession approached the court, the elders with alym, leaving the relatives of the killer at a respectful distance from the court of mourning, together with the Prince and honorary villagers approached the destination. They uttered the words of greeting (salama), performed the so-called prayer (dua), delivered a sermon about forgiveness and peaceful life. Then the representative of the elders approached the oldest of the family of the victim, sitting in the yard of mourning (taziat), and, giving him alym said: "This alym is given by (such) Prince". Taking the alym, the relatives of the victim faced to the relatives of the killer. This ended the rite of alym presenting and the so-called date of both parties. After that, the conciliators, together with the relatives of the killer, returned home. Before returning, they said, "God will send his peace". The killer was sent as a kanly (blood enemy) to other villages. If he was found and killed there by the relatives of the victim, they said, "Blood for blood" and it was forgotten. If they could not kill him, he was as a kanly until his relatives reconciled with him. The relatives of the killer, after reconciliation with the relatives of the victim, should not have left their cautious attitude towards them. In cases when a relative of the victim killed a relative of a killer who gave alym, such a killer was a blood enemy"kanly" of the Prince for a year from the day of the murder. No one took such blood enemy-"kanly" of the Prince and no one gave him the shelter. It was important to note that, by means of Maslaat investigations, among the Dagestan peoples not only litigation and disputes between individuals, but also hostile clashes between communities and nationalities were regulated.

Adats.

Adat (from Arab. "custom," from Avar. "bal") is an unwritten law based on a customary law, which reflected the norms of pre-Islamic legal complexes and the realities of legal life, not reflected by Shariat. Adat is also understood as customs and rules of conduct adopted by a group of Muslims, established in a certain region of the spread of Islam and observed mainly because of the habit.

Adats were inherently a system of social norms based on customs usually of nonIslamic origin. Many of them developed even in the context of the prevalence of maternity relations and pagan beliefs. It is generally accepted that the Highlanders knew the provisions of Adat, applied and respected them in everyday public life, as well as in judicial proceedings, and passed them verbally from generation to generation.

Having emerged even in clan system as customs and morals governing the relations of people, they have undergone a long evolution and transformed in modern culture as all traditions and customs rooted in the life of people and reflected in their minds. The epithet "unwritten" was often applied to Adats, because most of the "domestic", legal Adats (according to B. Dalgat), dealing mainly with the norms of social and family life, had not previously been specified in any normative documents. The available "printed collections of Adats concern only criminal or procedural Adats" - wrote B.V. Dalgat [3, 83 p.]. This gap was perfectly closed by him (B. Dalgat) in his work "Materials on the customary law of Darginians", where he described the domestic Adats of Darginians. Domestic Adats of the Avars are described in the work of G. Tsadas "Adats about marriage and family of the Avars from the 19th till the beginning of the 20th centuries", where they are clearly spelled out among the Avars. The classic collections of Adats are also "Collection of Adats of the Avar People" (compiled in the 11th century by Omarhan of Avar); "Collection of Adats of Rustam Khan of the 12th century; Collection of Kaitag Adats of the 16th century (compiled by the ruler Akhmat).

We cannot but agree with V.K. Gardanov, who notes: "It is possible to say without exaggeration that Adats of the Highlanders of the North Caucasus are the most important and sometimes the only source for the characterization of social relations among these 
peoples for many centuries, since the Middle Ages and especially for the period of the 18th - the beginning of the 19th centuries" [2, 19 p.].

Thus, the rules of law covered by "Adat" during the period under review can distinguish three types of legal relations: relations of "ethnographic" domestic character, legal customs and the rules of law themselves. The investigation of the case, the judicial proceeding, as a rule, began when there was an oral statement of the victim (the plaintiff) or his next of kin. Not only the cases of members of the society were taken, but also of outsiders being in the territory at the time of the offence. The claims were of two types: direct (with evidence) and on suspicion. Adat evidence was considered to be own confessions without coercion; an oath (people defined the number of sworn people themselves, usually at least two); sworn testimony of a wounded or dying person; material evidence (scratch marks, blood on weapons, etc.), as well as written documents confirmed with the oath. It was required in the claims on suspicion that the plaintiff together with the people making an oath would confirm his demands with oath or the defendant and the suspect would make a cleansing swear. The term of the oath lasted until the sunset, after which it was considered that the oath was not sworn by the party who did not appear with the people making an oath on the appointed day.

In some societies, a person who refused to "purify" a suspect was found guilty himself. In order to protect themselves from vain accusations, in proof of their innocence, people sometimes resorted to an oath that was of the nature of a public vow, such as, "If I killed a man, let no one read a prayer at my tombstone" or "if I am guilty, let something happen".

With the strengthening of Islam among the Avars, an oath form with the touch of a hand (palm) onto the Koran also appeared. It is believed that the oath "Khatun-Talak" is associated with the same norms (of Islam) (for example, if I stole cattle, I will divorce my wife); in the case of a false oath, the man was denied the right to his wife. The following persons were not involved in the oath: a person, who made a vow of refusal to take the oath, a slave and an employee. The man who gave the elders a cow was also provided with the right not to be involved in the oath by the elders who had taken a gift. Also, unmarried boys and girls and two persons from the same household were not involved in the oath [1, 133 p.]. The number of witnesses and the people making an oath was largely determined by the nature of the crime and the size of the claim. So, in murder cases, up to 50 people were required and 1 person was required for the theft of a sheep. For the cleansing oath it was necessary: in case of theft -6 people, theft of a horse - also 6 people, etc. The greatest number of oaths was required to cleanse the man accused of adultery - 15 people and among them close relatives could not be appointed.

At the same time, "the person who cleansed the suspect once cannot be appointed to cleanse the same person for another crime committed earlier than a year. The person who was caught giving a false certificate or taking a false oath also could not take part in the oath. The perpetrator of the false oath was subjected to a fine.

It should be noted that making a false oath was rare and here the deterrent for the people was not so much monetary punishment in the form of a fine as public censure. In this case, public opinion was an effective means of ideological and psychological coercion, on which the observance of moral principles and provisions developed in society was based. "Old morality was supported by the power of public opinion, age-old traditions, old habits, the system of education", R. Magomedov stressed [7, pp. 202-203].

The Village Court met in time free from agricultural work, if the application did not require immediate proceedings, i.e. if anyone's actions did not cause moral or material damage to the interests of the community as a whole; did not relate to an attempt on the honor of a woman or other unlawful act that could have resulted in blood revenge. As a rule, trials were conducted openly, publicly, except for affairs concerning rape, withdrawal, abduc- 
tion of women and maidens when private meetings with minimum of witnesses were required. The decision of the court was usually not subjected to appeal, the sentence commenced immediately. The exceptions were cases when time for reimbursement of heavy fines and compensation was given, as well as some cases were reviewed by the court of intermediaries with the mutual consent of the parties (the Maslaat World Court).

Specialists in Caucasian studies noted that Adat-legal systems of Dagestan were united in the main provisions. Thus, M.M. Kovalevsky wrote that "despite the variety of tribal composition and languages, residents of Dagestan adhere to more or less identical basis of rights" [5, 103 p.]. In his work he also noted that despite the great diversity of peoples and societies in Dagestan we are dealing with a unified legal system "common and basic provisions equally penetrate the customs of the Avars and the Andes, the Darginians and the Tabasaranians" [5, 104 p.].

Thus, the feature of Dagestan Adats of different societies and settlements is that with all the unity of codes and provisions, no paragraph repeats the other literally, i.e. all of them are of a private nature. This determined their differences, which could be expressed in different degrees of punishment, fine, number of the people making an oath, etc. Each jamaat (community) had its own code based on common, i.e. single Adat right in Dagestan is divided into many codified codes which were distributed into Adats of specific Jamaats.

If we sum up many common signs, the cases considered according to Adats of the peoples of Dagestan can be grouped according to the following points:

- Murder and bloodshed;

- Injuries, injuries;

- Quarrels and fights;

- Marriage brokerage and abduction of women;

- Insult, rape of women;

- Debauchery, adultery;

- Theft (robbery);

- Arson and damage to property of others;

- Land disputes, complaints;

- Complaints of violation of various public regulations;

- Lost and found items.

Adat also provided for certain penalties for committed crimes. The penalties provided by Adat for the crimes were as follows:

1. Expulsion from the village, granting the offended and his relatives the right to kill the expelled person with impunity or to forgive him on known terms. This type of punishment is commonly called "exit to kanly" (from Turkic languages kan is blood), kanly is a blood enemy.

2. Expulsion from the village for a certain period of time, but without granting the offended the right to kill the expelled.

3. Collecting money or property from the perpetrator in favor of the offended. This form was determined mainly for dishonor, wounds, injuries, theft. The amount of the penalty depended more often on the importance of the case.

4. Ishkil (from the East languages "Shekil" is a unit of money of the Ancient East) is the seizure of property to force the defendant to satisfy property claims or other obligations. It happened that sometimes the property of the debtor's jamaat was seized to force him to pay (it is one of the varieties of Adat incompatible with Shariat).

5. Alym (from Turkic languages this word means "taken") is collected always from the killer and his relatives according to a special arrangement soon after the murder. 
6. Diyat (from Arab. the word means "reward") is a special fee for which persons entitled to bloodshed agree to forgive the killer. The feature of diyat is that it is paid if the truce of the warring parties took place.

The death penalty did not exist according to Adat, but in many cases there was a right to kill the perpetrator: a man who was dishonest to the family, a man declared an enemy of society; a thief caught at the crime scene; women caught with a lover, etc. Thus, personal grievances and the most serious crimes (for example, violence) were not subjected to trial. The Highlanders also did not know such a form of punishment as imprisonment. At the same time, the person who committed the evil always had the opportunity to leave, so Adat allowed bloodshed or the right of kanly (blood enemy), not only to the guilty, but also to the relatives. For example, in Unkratla (an administrative unit within the Dagestan region and the Dagestan Autonomous Soviet Socialist Republic, which existed in 1861), the murder of a blood enemy before reconciliation was considered unpunished. "If the man kills the blood enemy before the reconciliation, he is not punished for this, the dispute also ends if a member of the blood enemy`s family is killed" [9, pp. 58-59]. Therefore, "the killer and relatives, for three days after the murder, while living in their village must remain in hiding and not be shown; after three days, when the relatives of the killer go to the relatives of the victim with a winding sheet and a bull to reconcile with them, they can live as other fellow villagers live" [9, 63 p.]. If after the blood enemy was expelled from the aul, the relatives of the victim killed the brother of the blood enemy or another relative, 100 sheep were recovered from the killer. In addition, he was obliged to return diyat that he had received from his blood enemy, and his entire family was condemned to eternal exile without the right to return to the aul.

Let us give examples of Adats of murders in different societies to trace similarities and minor differences in them.

Adats of the Tindalsky naibstvo (administrative division):

- By court order the killer pays relatives of the murdered 250 rubles of diyat, he is expelled as a kanly to the far district for an indefinite period. In case of accidental murder, he pays relatives of the victim 50 rubles, gives a winding sheet, a bull and buys at the cemetery a plot of land for the grave of the victim.

Adats of the Andean naibstvo (administrative division):

- For premeditated and any murder, wherever it is committed, 100 rubles are recovered from the killer in favor of relatives of the murdered by court order, 50 rubles from these 100 rubles are handed over to relatives of the victim by relatives of the killer. After 3 days they with smart and honorary people from society and women go to the house of the victim with a bull for reconciliation and 50 rubles after the decision of the court. Before reconciliation the killer has no right to plough the fields, to mow hay and to use his property freely at all, although he may stay in his house and his village, but the relatives of the victim always have the right to trace him.

- The son for the murder of the father is deprived of the right to inheritance, he becomes a kanly and he is responsible to other brothers for the blood of the father;

If the husband kills the lover and the wife, he is not responsible for the blood; If he kills only the lover, he takes responsibility as a blood enemy.

Adats of the Kelebskiy settlements:

- If the brother kills the sister or the husband kills the wife or the cousin kills the cousin, finding them with a stranger, then nobody will look for their blood, it will disappear (it means that there will not be blood revenge, bloodshed).

As we can see, compensation for personal injury was accompanied by payment of the so-called "blood price" (composition) or eviction of the perpetrator (traditions of ostracism) and his family from the native village for a time or forever. The size of these compositions was not small and therefore the members of the family, tukkhum (a tribe, a family), 
took part in their payment. The composition for the murder of a woman was lower than for the murder of a man, although for other crimes against a woman Adat penalties were stricter. For example, Adats of the Darginsky district stated that the perpetrator was not punished for "beating a man, even with remained signs, as well as for causing a wound that did not require treatment.

The main forms of conflict regulation in the culture of pre-revolutionary Dagestan remained Maslaat and Adat. At the same time, Islamic clergy in the regulation of conflict situations tried to introduce Shariat norms (a set of regulations defining beliefs, as well as forming religious conscience and moral values of Muslims). In the cultural and legal field of pre-revolutionary Dagestan Shariat had not managed to displace the norms of Adat.

After analyzing a number of factors, we identified the main reasons why Shariat had not displaced Adats:

1. Adats, even before the approval of Shariat, had got into the life of the Highlanders firmly, and became their tradition and the basis of their lifestyle and morality.

2. Adats are closer and more understandable for the Highlanders.

3. According to many Highlanders, Shariat provided too severe penalties for some crimes that were considered minor by Adat (for example, theft).

To the question of the severity of punishment according to Shariat, let's give an example of one Adat from the collection of Adats of Tarkovsky Shamkhalate and Mekhtulinsky Khanate. Adat on the retreat from faith said: "For the retreat from the Muslim religion, the perpetrators, if they are in the power of society, are immediately killed according to Adat, and according to Shariat they are initially called to repent and return to Islamism. If one who retreats from the Muslim religion has time to escape, he is deprived of all inheritance rights".

4. The Highlanders believed that it was difficult to envisage all the nuances of a multifaceted human life according to Shariat, as this required educated people with perfect knowledge of the Koran and Sunnah, and people able to interpret knowledge correctly.

5. Adats have always been means of replenishment of the budget of leadership elite: bek (the category of privileged population), uzden (the feudal class in the Caucasus), etc. In their elimination they saw a real threat of their financial wellbeing.

Thus, due to these main reasons and the resulting circumstances, Adats in the culture of pre-revolutionary Dagestan continued to exert a strong influence on public life and therefore were fully guided by their norms in criminal matters in the Dagestan society of the pre-revolutionary period. This did not exclude the fact that in many villages Shariat had a significant impact on the content and on the norms of Adat.

At present, the norms of Adat and Shariat continue to have a significant impact on the life of Dagestan. But if earlier in the culture of pre-revolutionary Dagestan they represented the system of judicial proceedings, today they more affect various aspects of private life of people, having transformed from the system of regulation of conflict situations into customs, traditions and norms of Dagestan.

\section{Лumepamypa}

1. Адаты Тиндальского наибства Хваршинского общества. Гл.1. № 11.

2. Гарданов В. К. Обычное право, как источник для изучения социальных отношений у народов Северного Кавказа в XVIII- нач. XIX вв. СЭ. 1960. № 35.

3. Далгат Б. В. Материалы по обычному праву даргинцев. Из истории права народов Дагестана. С.77-144.

4. Иващенко А.П. Архетипы коллективного бессознательного и этническая идентичность // Гуманитарные и социально-экономические науки. 2015. № 6 (85). С. 21-24. 
5. Ковалевский М.М. Закон и обычай. Т.2. М., 1890. С. IX.

6. Комаров А. В. Адаты и судопроизводство по ним. ССКГ. Тифлис, 1868.

7. Магомедов Р.М. Дагестан. Исторические этюды. Махачкала: Дагкнигоиздат, 1971.

8. Мустафраева М.Г., Мустафраев М.В. Вопросы социально-психологического поведения личности: национальные и этноконфессиональные аспекты // Известия Северо-Кавказского научного центра высшей школы. Естественные науки. 1987. № 2. C. 95.

9. Памятники обычного права народов Дагестана XVII-XIX вв. Наука.1965.

10. Цечоев В.К. Современная историография развития отечественной юстиции // Гуманитарные и социально-экономические науки. 2013 . № 5 (72). С. 78-82.

11. Petrenko S.P. Application of ethnic and national terminology in research of South Russian people // Научный альманах стран Причерноморья. 2015. № 2.

\section{References}

1. Adaty Tindalskogo naibstva Khvarshinskogo obshchestva. [Adats of the Tindalsky naibstvo of Khvarshin society]. Chapter 1. No. 11 (in Russian).

2. Gardanov V. K. Obychnoe pravo, kak istochnik dlia izucheniia sots. otnoshenii u narodov Severnogo Kavkaza v XVIII- nach. XIX vV. [Customary law as a source for studying social relations in the North Cacasus in the 18 - beginning of the19th century]. SE. 1960 No. 35. (in Russian).

3. Dalgat $B$. V. Materialy po obychnomu pravu dargintsev. Iz istorii prava narodov Dagestana. [Materials on the customary law of Darginians. From the history of law of peoples in Dagestan]. pp. 77-144 (in Russian).

4. Ivaschenko A.P. Arkhetipy kollektivnogo bessoznatelnogo i etnicheskaia identichnost. Gumanitarnye i sotsialno-ekonomicheskie nauki. [Archetypes of the collective unconscious and ethnic identity. Humanitarian and socio-economic sciences]. 2015. No. 6 (85), pp. 21-24 (in Russian).

5. Kovalevsky M. M. Zakon i obychai. [Law and Custom]. V.2. Moscow, 1890.,9 p. (in Russian).

6. Komarov A. V. Adaty i sudoproizvodstvo po nim. [Adats and their proceedings]. SSKG. Tiflis, 1868 (in Russian).

7. Magomedov R.M. Dagestan. Istoricheskie etiudy. [Historical etudes]. Makhachkala: Dagknigoizdat, 1971 (in Russian).

8. Mustafayeva M.G., Mustafayev M.V. Voprosy sotsialno-psikhologicheskogo povedeniia lichnosti: natsionalnye i etnokonfessional'nye aspekty. Izvestiia SeveroKavkazskogo nauchnogo tsentra vysshei shkoly. Estestvennye nauki. [Issues of social and psychological development of personality: national and ethno-religious aspects. News of the North Caucasus Scientific Center of Higher School. Natural Sciences]. 1987. No. 2. 95 p. (in Russian).

9. Pamiatniki obychnogo prava narodov Dagestana XVII-XIX vV. [Monuments of customary law of the peoples of Dagestan XVII-XIX centuries] (in Russian).

10. Tsechoyev V.K. [Modern historiography of development of domestic justice. Humanitarian and socio-economic sciences]. 2013. No. 5 (72), pp. 78-82 (in Russian).

11. Petrenko S.P. [Application of Ethnic and National Terminology in Research of South Russian People. Science Almanac of Black Sea Region Countries]. 2015. No. 2. 